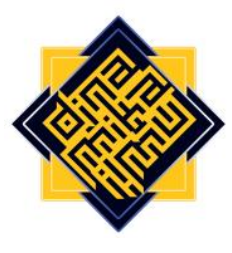

\title{
Challenges of Managerial Functions Emerging within IGRA Professional Organizations in East Kalimantan
}

\author{
Ity Rukiyah \\ State Islamic Institute of Samarinda, Indonesia \\ e-mail:kampusity123@gmail.com \\ Marniati Kadir \\ State Islamic Institute of Samarinda, Indonesia \\ e-mail: marniati17samarinda@gmail.com \\ Zakiyah Ulfah \\ State Islamic Institute of Samarinda, Indonesia \\ e-mail:ulfah.zack@gmail.com
}

Abstract

The function of Ikatan Guru Raudhatul Athfal, or what so-called by IGRA is ideally as a forum for professional development of educators and educational members of Early Childhood Education or ECE institutions. This research is aimed to figure out challenges faced by IGRA in East Kalimantan in relation to principles of organizational management i.e, planning, organizing, actuating, and controlling, or what so-called by POAC. In-dept interview was done to the head and members of IGRA in East Kalimantan in four different cities i.e, Samarinda, Balikpapan, Tenggarong, and Berau. Findings of this research indicate that principles of organizational management have not effectively been employed due to very crucial challenges, including leadership, organizational funding, IGRA members competency, government support, and some other critical barriers that trigger insufficient management implementation of IGRA in East Kalimantan. Research implications and suggestions are discussed further in this research.

Keywords: challenges, IGRA, principles of management, professional organization 


\section{A. Introduction}

A professional organization is a forum for associations of people who have special expertise which carried out continuous activities and agenda. In this case, a professional organization in Indonesia such as Raudhatul Athfal Teacher Association or what so-called IGRA is ideally managed according to management functions. Management functions are activities which are contained in the managerial process. McNamara (2009) noted that there are five basic elements in management which proposed by Henri Fayol over 90 years ago i.e, planning, organizing, commanding, coordinating, and controlling. Meanwhile, Terry (1986) pointed out that there are four principles in management, including planning, organizing, actuating, and controlling.

Management can also functioned in building creativity and innovation for administrators in an organization (McKeown, 2019). In this case, creativity is important because its existence can improve the quality of management where it refers to the combination of old ideas in new ways. Other than that, innovation is also important because it contains the process of collaboration of people involvement, both inside and outside the organization. Having a well-managed organization is very important, so that researches regarding with management becomes interesting and useful to many professional organizations to be done in many aspects (Hanim, 2019; Ilyasin, 2020, 2019; Mahmud, 2012; Na'imah, 2018; Zamroni, 2019).

Specifically, IGRA, as one of the professional organizations for Early Childhood Education or what so-called ECE plays a vital role in the development of early childhood education. Specifically, IGRA was founded in 2002 which functioned to carry out programs aimed at increasing the professionalism of educators and educational staff as well as ECE graduates. Thus, this professional organization has a major and strategic role in improving the quality of ECE institutions.

The existence of IGRA in East Kalimantan has been quite long and of course, has contributed a lot to improving the quality of ECE institutions. However, some researches showed that IGRA in East Kalimantan had not been managed properly. This fact is certainly influenced by problems and challenges where commonly professional organizations often faced. There are problems and challenges including quality of teachers (Dina, 2013; Omebe, 2014; Listiyowati, 2017; Rahminawati et al., 2019), leadership (Mulford, 2003; Tobin, 2014), limited funds (Cheruto \& Benjamin, 2010; Galafa \& Lucas, 2018), shortage of staff (Cheruto \& Benjamin, 2010), government support (Rahminawati et al., 2019), competencies of learning evaluation (Rohmadheny et al., 2019). Therefore, in order to overcome problems and challenges faced by the professional organization, especially for $E C E$, some efforts are done to increase the quality of ECE service, such as by giving workshops (Rahminawati et al., 2019), lesson study by using a scientific approach (Yennizar et al., 2020).

The above relevant studies indicate how fascinating the study regarding with ECE in relation to organizational management as well as how they solve problems and accept challenges. Therefore, this research is intended to study regarding with problems and challenges faced by IGRA as one of ECE professional organizations in East Kalimantan. Specifically, there were IGRA in four different cities that became the research sites i.e 
Samarinda, Balikpapan, Berau, and Tenggarong. In this case, the researchers observe the challenges faced by IGRA in East Kalimantan in relation to the basic principles in management i.e, planning, organizing, actuating, and controlling or what so-called by POAC proposed by Terry (1986) and Terry \& Rue (2015).

\section{B. Literature Review}

\section{IGRA as Professional Organization}

In general, an organization can be defined as a collaboration among humans as a whole which functioned is to interact with each other to achieve a goal (Syafaruddin, 2015). It is a place for various management activities so that the goals can be achieved effectively and efficiently (Nawawi, 1992). Organization goals can be achieved under the direction of the leadership with agreed rules by the use of all organizational resources e.g, human resources and organizational funds. An organization has a structure and interconnected goals to coordinate activities (Ardial, 2018). Other than that, human resources are the most important element in an organization because, from human resources, an organization will have decision making, goal setting, implementation, and job evaluation (Rahminawati et al., 2006). Additionally, elements of the organization include rules set in a system, consist of a group of people, has goals to be achieved, division staff, organizational resources, cooperation, and coordination (Agus, 2016; Rahminawati et al., 2006).

In the more particular context of education in Indonesia, professional organizations of education in Indonesia still focus on their development function. Meanwhile, the functions of advocacy and regulation i.e, standardization, accreditation, certification, and licensing, are still controlled by the Educational Institutions and Education Personnel (LPTK) (Farisi, 2013). For instance, PGRI as a teacher professional organization is an association with legal status as a forum for professional development, legal protection, occupational safety, and aspiration for teachers (Yuniastutik, 2013).

IGRA, as one of the professional organizations within the Ministry of Religion, is a forum for guidance and cooperation between school principals and teachers of Raudhatul Athfal (RA), Bustanul Athfal (BA), and Tarbiyatul Athfal (TA) in providing pre-school education (children aged 4-6 year) (Rokhzi, 2016; Noor, 2016). IGRA involvement improves the quality of RA human resources so that IGRA IGRA can be an agent of local researchers and organizers (Wardany, 2019; Muslam et al., 2017). Furthermore, IGRA plays an important role in enhancing the professionalism of RA, BA, and TA teachers (Zahroh, 2014), especially to master up-to-date educational teaching aids (APE), the use of technology, especially ITbased learning, where it becomes one of the challenges for RA teachers in 4.0 educational era (Hidayatulloh \& Anis, 2017).

Furthermore, IGRA's vision is the realization of Islamic, qualified, and professional RA teachers. At the same time, the mission of Igra includes realizing Islamic, qualified, and competitive RA, BA, and TA teachers, preparing RA, BA, and TA teachers to have good character and achievement, establishing Islamic brotherhood, building IGRA as a professional organization for RA, BA, and TA teachers (Peraturan Organisasi Ikatan Guru Raudhatul Athfal, 2018a). As a professional organization, IGRA has several objectives i.e, 
building Islamic and competitive creation of RA, BA, and TA educational institutions, shaping good characters and increasing achievement of RA, BA, and TA teachers, creating Islamic brotherhood among IGRA members, becoming a professional organization, having professional teachers and staff, and increasing teachers and staff welfare (Peraturan Organisasi Ikatan Guru Raudhatul Athfal, 2018b; 2018c).

\section{Basic Principles of Management: Planning, Organizing, Actuating, and Controlling}

Terminologically, management means to manage or to organize where its intention is to bring, achieve, and responsible in running management (Wijaya \& Rifa'i, 2016). In an organization, leadership is very important where a manager should carry out managerial activities to mobilize human resources effectively so that organizational goals can be achieved (Kaswan, 2016). In addition, management is a framework that involves guidance for a group of people towards organizational goals or the use of resources (Rifa'i \& Fadhli, 2013). In other words, it can be concluded that management is a process of planning, coordinating, mobilizing, and controlling various activities carried out by a group of people by utilizing the use of resources effectively and efficiently in order to achieve the goals (Terry \& Rue, 2015; Sitorus, 2019).

Above explanation about the basic concept of management drives to management functions or basic principles in organizing a management system. In this case, a famous expert i.e, Goerge R. Terry, proposed that in management, there are four vital principles, including planning, organizing, actuating, and controlling or what so-called by POAC (Terry, 1986; Terry \& Rue, 2015; Wijaya \& Rifa'i, 2016). To the more particular aspect regarding with basic principles of management, planning is the first step where members in an organization should accomplish first because planning consists of activities that will be carried out in the future (Tegar, 2019; Nurhayati, 2014). As Allah says in QS. Al Hasyr: 18, "You who believe! Be mindful of God, and let every soul consider carefully what it sends ahead for tomorrow; be mindful of God, for God is well aware of everything you do" (Arifin, 2019).

The next point in organizing, organizational members and resources are managed to carry out plans and achieve the goals set in the first step, which is planning. It is related to the formation of job descriptions and distribution to each work division. This management activity is aimed to prevent overlapping in work responsibilities between each division (Nurhayati, 2014; Arifin, 2019). The third aspect of management principle is actuating, which means is a form of means, efforts, methods, and techniques to motivate subordinates to work sincerely in order to achieve organizational goals effectively and efficiently (Mukminin, 2011). In this actuating process, motivation needs to be given to organizational members in order to build commitment and responsibility towards the mandate given. Additionally, its function is to build harmonious relationships and cooperation among members of the organization as well as building networks with other organizations. Other than that, actuating is intended to mobilize the tasks, functions, responsibilities, and authorities organized can be carried out in accordance with the policies and plans that have been set, either through directing, coordinating, encouraging, or leading (Wahyudin, 2014). 
Lastly, the aspect that should be existed in management is controlling. In this part, controlling is aimed to control and evaluate organizational plans so that their implication is in accordance with plans and goals that have been set (Mukhneri, 2010). Moreover, in order to ensure all of the organizational members mobilize the organizational objectives or goals, there is corrective action done by a leader. The aspect of supervision which contains conrrection drives to positive impact in optimizing the functions and the role of the community (Nurhayati, 2014).

\section{Research Methodology}

This research is field research where data collection was carried out a phenomenon in a scientific situation (Moleong, 2004). A qualitative approach is used in this research (Miles et al., 2014; Gay et al., 2012) where a case study is the research design in order to capture natural phenomenon happened (Creswell, 2008; 2014; Taylor et al., 2016; Yin, 2011; Merriam, 2009) especially regarding with problems and challenges faced by IGRA East Kalimantan in relation to the basic principles of management i.e., planning, organizing, actuating and controlling, or what so-called by POAC. Moreover, the result of the study focuses more on meaning and process rather than generalization (Susilo, 2013; Sugiono, 2009). In-dept interview was done with the head and staff of IGRA in East Kalimantan, particularly in four different cities i.e. Samarinda, Balikpapan, Tenggarong, and Berau.

\section{Findings and Discussion}

Findings in this research is displayed based on the challenges faced by IGRA in East Kalimantan in relation to POAC, which is proposed by Terry (1986) and Terry \& Rue (2015). Specifically, the below chart displays the sort of challenges faced by IGRA in East Kaimantan.

\section{Challenges Faced by IGRA in East Kalimantan}

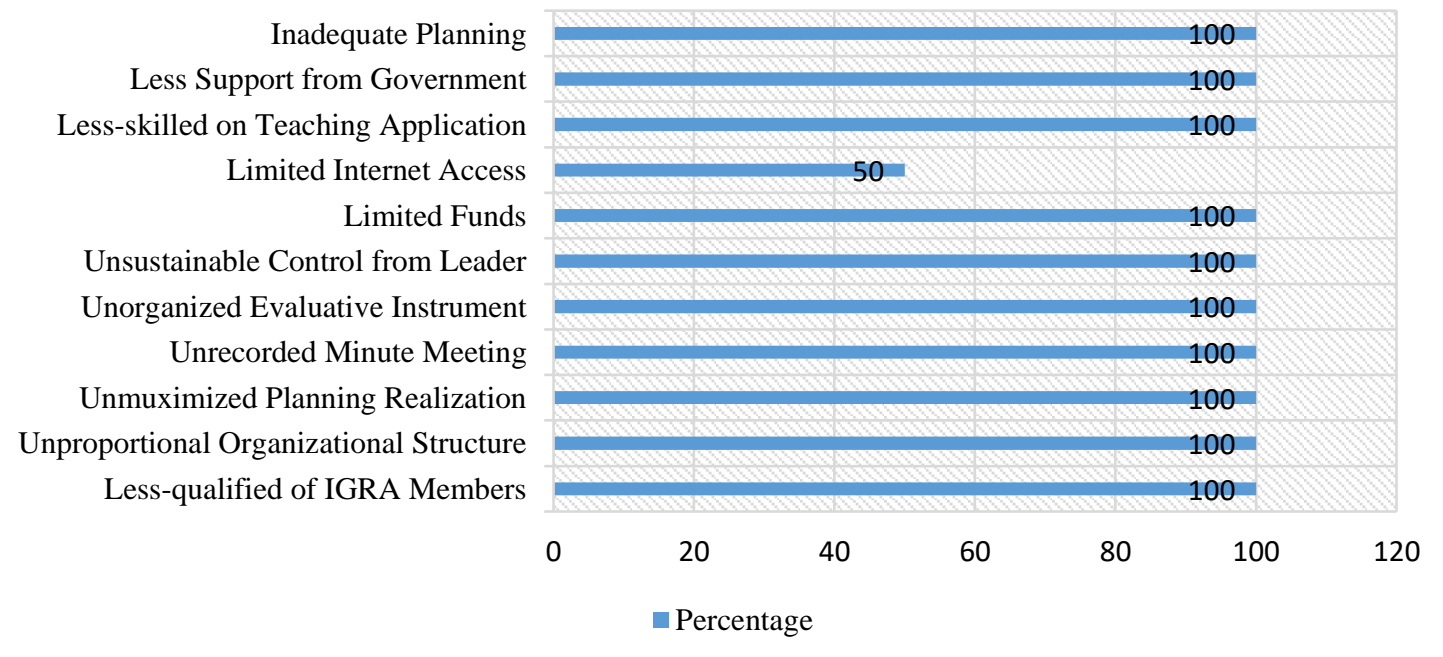

Figure: The challenges faced by IGRA in East Kaimantan 
Findings visualized on the above chart indicate an extreme percentage where ten out of eleven aspects that become the challenges in IGRA management of East Kalimantan reach maximum percentage. It means that IGRA, as one of ECE professional organizations, needs special attention from the government as less support from the government also becomes one of the challenges faced by IGRA. This finding is supported by the research from Rahminawati et al. (2006) where the lack of support from the government indeed becomes a barrier in the development of ECE institution. For instance, one of the support actions from government which is needed by IGRA is in terms of funding. In this case, the members often use their personal budget to implement the program of IGRA. In short, it can be said that limited funds is a problem that is critical to the sake of programs implemented by an organization (Cheruto \& Benjamin, 2010; Galafa \& Lucas, 2018).

Not only from the government but the challenge from the internal aspect also seems to appear related to human resources. In this case, most of IGRA members in East Kalimantan are only from Diploma graduation where ECE teachers nowadays at least have bachelor's degree for sure. Certainly, the competencies of ECE institution is vital where it will impact to all aspect in principles in organizational management (Rahminawati et al., 2006; Dina, 2013; Omebe, 2014; Listiyowati, 2017). Additionally, IGRA in East Kalimantan has disproportionate members, so that it certainly influences the structure of organization and job division. As Cheruto \& Benjamin (2010) found that the shortage of staff is crucial to be one of the obstacles in implementing institutional programs. This fact designates that the shortage of staff or members in an organization affects the programs planned and the implementation of the programs in the organizing aspect in management.

Moreover, another point that makes management of IGRA in East Kalimantan is not well-managed is indicated from no documentation or minute meeting in every meeting they make whether when planning, implementing, and evaluating or controlling the IGRA programs. It is very difficult for IGRA as there is no documentation in a professional organization where they should have relied on and followed the meeting decisions regarding with the IGRA programs. This challenge results in inadequate planning and its realization as well as giving direct impact to the future organizational planning.

Furthermore, in the controlling aspect of management, IGRA organizations in East Kalimantan face barriers in two matters i.e, unsustainable control from the leader and unorganized evaluative instrument as what also found by researches from Rohmadheny et al. (2019), Tobin (2014), and Mulford (2003) where the success of an institution depends on the leader. Therefore, efforts to improve the quality of a leader are crucial for an organization. Particularly, in evaluation section, which is existed in the controlling part, there is no instrument of evaluation such as questionnaires etc., so that it affects future planning where there is no improvement of the IGRA quality.

The last point that becomes one of the challenges faced by IGRA is regarding with 4.0 era. In this case, all of the IGRA members are literated to the use of the internet even though two of IGRA organizations located in Tenggarong and Berau are often feel difficult to have a smooth internet connection. Additionally, most IGRA members are not familiar with the 
use of the online application to support ECE teaching and learning in this 4.0 educational era.

\section{E. Conclusion}

The shortage of IGRA in implementing the organization, which has a direct impact on the principles of management of IGRA comes to eleven critical aspects which are generally related to leadership, funds, members competency, and government support. Additionally, regarding with the era of 4.0 education, the researchers found that most of IGRA members are not accustomed to the use of updated online applications, especially in its usage in teaching and learning of ECE context. Finally, based on this research results, the researchers suggest that government support for IGRA plays an important role, especially in terms of funding support for program implementation of IGRA in East Kalimantan. The support from the governement is also important to improve members of IGRA competency, especially in the use of technology such as creating seminars and workshops regarding with online application to be used by ECE teachers as members of IGRA.

\section{BIBLIOGRAPHY}

Agus, A. (2016). Manajemen Organisasi. IAIN Mataram.

Ardial, A. (2018). Komunikasi Organisasi. Lembaga Penelitian dan Penulisan Ilmiah Aqli.

Arifin, Z. (2019). Zainal Arifin, Tafsir Ayat-Ayat Manajemen Hikmah Idariyah Dalam AlQur'an. Prodi MPI FITK UIN Sunan Kalijaga.

Cheruto, K. L., \& Benjamin, K. W. (2010). Management challenges facing implementation of free primary education in Kenya: A case of Keiyo District. Journal of Education Administration and Policy Studies Vol., 2(January 1974), 71-76.

Creswell, J. W. (2008). Educational Research. Planning, Conducting, and Evaluating Quantitative and Qualitative Research (3rd ed.). Pearson Prentice Hall.

Creswell, J. W. (2014). Research Design: Qualitative, Quantitative and Mixed Methods Approaches. SAGE Publication Inc.

Dina, A.-T. (2013). Challenges Faced by Educational Leadership on Influencing Student Learning. Procedia - Social and Behavioral Sciences, 93, 290-295. https://doi.org/10.1016/j.sbspro.2013.09.192

Farisi, M. I. (2013). Dinamika Organisasi Profesional Kependidikan di Indonesia. Lembaran Ilmu Kependidikan, 42(1).

Galafa, B., \& Lucas, A. (2018). Challenges to Educational Administration and Management in Primary Schools in Malawi. North American Academic Research, 1(2), 1-14.

Gay, L. R., Mills, G. E., \& Airasian, P. (2012). Educational Research: Competencies for analysis and applications. Pearson.

Hanim, Z. (2019). Learning Innovation Management on Effective Classes at SMPIT Cordova Samarinda. DINAMIKA ILMU, 19(2), 225-236.

Hidayatulloh, M. A., \& Anis, U. (2017). Pemberdayaan Guru RA Kota Salatiga Dan Kabupaten 
Ity Rukiyah, Marniati Kadir, Zakiyah Ulfah

Semarang Untuk Meningkatkan Mutu Pembelajaran. Dimas: Jurnal Pemikiran Agama Untuk Pemberdayaan, 17(1).

Ilyasin, M. (2019). Discipline Management in Strengthening Modern Human Resources Dinamika Ilmu. DINAMIKA ILMU, 19(2), 351.

Ilyasin, M. (2020). Transformation of Learning Management: Integrative Study of Islamic Boarding School Curriculum. DINAMIKA ILMU, 20(1), 13-22.

Kaswan, K. (2016). Kaswan, Pengembangan Manajemen. Alfabeta.

Listiyowati, L. (2017). The Role of HIMPAUDI in the Development of PAUD Educators ' Competence in Semarang City. Early Childhood Education Papers (Belia), 6(1).

Mahmud, M. E. (2012). Motif Penyelenggaraan Pendidikan Islam dan Implikasinya pada Pola Manajemen dan Kepemimpinan. DINAMIKA ILMU, 12(2).

McKeown, T. (2019). Examining Management Buzzwords - Starting with Creativity and Innovation. Journal of Management \& Organization, 25(1).

McNamara, D. E. (2009). From Fayols Mechanistic To Todays Organic Functions Of Management. American Journal of Business Education (AJBE), 2(1), 63-78. https://doi.org/10.19030/ajbe.v2i1.4023

Merriam, S. B. (2009). Qualitative Research: A Guide to Design and Implementation. JosseyBass: A Wiley Imprint.

Miles, M. B., Huberman, A. M., \& Saldana, J. (2014). Qualitative Data Analysis: A Methods Sourcebook. SAGE Publications.

Moleong, L. J. (2004). Metodologi Penelitian Kualitatif. Remaja Rosdakarya.

Mukhneri, M. (2010). Manajemen Mutu Terpadu Pada Program Studi Manajemen Pendidikan S2 Pascasarjana Universitas Negeri Jakarta. Jurnal Manajemen Pendidikan, 1(1).

Mukminin, A. (2011). Manajemen Penyelenggaraan Pendidikan Anak Usia Dini. UNNES.

Mulford, B. (2003). School Leaders : Challenging Roles and Impact on Teacher and School Effectiveness. OECD Commissioned Paper, April.

Muslam, M., Fatkuroji, F., \& Khunaifi, A. (2017). Pemberdayaan Raudlatul Athfal (RA) melalui Peningkatan Kualitas SDM Guru di Daerah Nelayan Kecamatan Tugu Kota Semarang. Dimas: Jurnal Pemikiran Agama Untuk Pemberdayaan, 17(1).

Na'imah, N. (2018). Islamic Character Education Management in Developing the Empathy Values for Students Islamic of State University of Sunan Kalijaga Yogyakarta. Dinamika Ilmu, 18(2), 285-304. https://doi.org/10.21093/di.v18i2.1331

Nawawi, H. (1992). Hadari Nawawi, Administrasi Pendidikan. Haji Masagung.

Noor, F. A. (2016). Manajemen Guru Raudlatul Athfal (RA) Dalam Total Quality Management (TOM). QUALITY, 3(1).

Nurhayati, N. (2014). Manajemen Penyelenggaraan Layanan Pendidikan Sekolah Inklusi. Jurnal Manajemen Pendidikan, 5(1).

Omebe, C. A. (2014). Human Resource Management in Education: Issues and Challenges. British Journal of Education, 2(7), 26-31.

Peraturan Organisasi Ikatan Guru Raudhatul Athfal. (2018a). Anggaran Dasar Anggaran Rumah Tangga Bab II Pasal 3. Ikatan Guru Raudhatul Athfal. 
Peraturan Organisasi Ikatan Guru Raudhatul Athfal. (2018b). Anggaran Dasar Anggaran Rumah Tangga Bab II Pasal 4. Ikatan Guru Raudhatul Athfal.

Peraturan Organisasi Ikatan Guru Raudhatul Athfal. (2018c). Anggaran Dasar Anggaran Rumah Tangga Bab II Pasal 7. Ikatan Guru Raudhatul Athfal.

Rahminawati, N., AR, H. N., \& Muthia, U. (2006). Kemampuan Manajerial Pengurus Organisasi Dalam Upaya Meningkatkan Kinerja Organisasi Islam Perempuan di Jawa Barat. Jurnal Mimbar Unisba, 22(2).

Rahminawati, N., Hakim, A., Sobarna, A., \& Masnipal, M. (2019). Early Childhood Education Management Workshop to Improve the Quality of Pos PAUD Service. Advances in Social Science, Education and Humanities Research, 307(SoRes 2018), 89-94. https://doi.org/10.2991/sores-18.2019.20

Rifa'i, M., \& Fadhli, M. (2013). Manajemen Organisasi. Ciptapustaka Media Perintis.

Rohmadheny, prima suci, Nuraini, F. T., \& Setyaningrum, I. (2019). What are the Problems of Indonesian ECE Teachers in the Implementation of Learning Evaluation? International Conference on Early Childhood Development (ICECD), 2019, 24-28.

Rokhzi, M. F. (2016). Pendampingan Ikatan Guru Raudlatul Athfal (IGRA) Kecamatan Sooko Mojokerto Dalam Pengembangan Perangkat Pembelajaran Kurikulum 2013. Repository, 1(1).

Sitorus, J. (2019). Management in the Context of Organizational Development. Hijri, 8(1).

Sugiono, sugiono. (2009). Metode Penelitian Pendekatan Kuantitatif, Kualitatif dan R \& D. Alfabeta.

Susilo, S. (2013). Metode Penelitian Bidang Pendidikan. Kanwa Publisher.

Syafaruddin, S. (2015). Manajemen Organisasi Pendidikan Perspektif Sains Dan Islam. Perdana Publishing.

Taylor, S. J., Bogdan, R., \& DeVault, M. L. (2016). Introduction to Qualitative Research Methods : a Guidebook and Resource (4th ed.). John Wiley \& Sons, Inc.

Tegar, N. (2019). Manajemen SDM dan Karyawan. Quadrant.

Terry, G. R. (1986). Azas-Azas Manajemen. Alumni.

Terry, G. R., \& Rue, L. W. (2015). Dasar-Dasar Manajemen. Bumi Aksara.

Tobin, J. (2014). Management and leadership issues for school building leaders. NCPEA International Journal of Educational Leadership Preparation, 9(1), 76-89. http://files.eric.ed.gov/fulltext/EJ1024110.pdf

Wahyudin, I. (2014). Manajemen Kurikulum. Remaja Rosdakarya.

Wardany, D. K. (2019). Pemberdayaan Ikatan Guru Raudhatul Athfal (IGRA) Dalam Meningkatkan Kompetensi Kepala RA di Kabupaten Majalengka. JURNAL PARAHITA ABDIMAS, 1(1).

Wijaya, C., \& Rifa'i, M. (2016). Dasar-Dasar Manajemen. Perdana Publishing.

Yennizar, Y., Zulqarnain, Z., Eriyani, E., Zukhairina, Z., Susanti, N., \& Kausari, D. (2020). Application of Lesson Study With a Scientific Approach: a Case Study of Early Childhood Education. Journal of Critical Reviews, 7(07), 104-111. https://doi.org/10.31838/jcr.07.07.17

Yin, R. K. (2011). Qualitative research from start to finish. The Guildford Press. 
Ity Rukiyah, Marniati Kadir, Zakiyah Ulfah

Yuniastutik, L. (2013). Implementasi Kebijakan Organisasi PGRI Dalam Mengembangkan Profesionalisme Guru Di Kecamatan Wagir Kabupaten Malang. Jurnal Pendidikan, 1(1). Zahroh, L. A. (2014). Peningkatan Profesionalisme Guru Raudhatul Athfal. Ta'allum: Jurnal Pendidikan Islam, 2(1).

Zamroni, Z. (2019). Innovation of Learning Management in Madrasah Level. Dinamika Ilmu, 19(2), 337-349. 